\title{
Therapeutics for Alzheimer's Disease Based on the Metal Hypothesis
}

\author{
Ashley I. Bush*† and Rudolph E. Tanzi ${ }^{\ddagger}$ \\ *The Mental Health Research Institute, 155 Oak Street, Parkville, Victoria 3052, Australia; ${ }^{\dagger}$ Department of Pathology, \\ University of Melbourne, Grattan Street, Parkville, Victoria 3010, Australia; and ${ }^{\ddagger}$ Genetics and Aging Research Unit, Mass \\ General Institute for Neurodegenerative Disease, Department of Neurology, Massachusetts General Hospital, Charlestown, \\ Massachusetts 02129
}

\begin{abstract}
Summary: Alzheimer's disease is the most common form of dementia in the elderly, and it is characterized by elevated brain iron levels and accumulation of copper and zinc in cerebral $\beta$-amyloid deposits (e.g., senile plaques). Both ionic zinc and copper are able to accelerate the aggregation of $\mathrm{A} \beta$, the principle component of $\beta$-amyloid deposits. Copper (and iron) can also promote the neurotoxic redox activity of $\mathrm{A} \beta$ and induce oxidative cross-linking of the peptide into stable oligomers. Recent reports have documented the release of $\mathrm{A} \beta$ together with ionic zinc and copper in cortical glutamatergic synapses after excitation. This, in turn, leads to the formation of $\mathrm{A} \beta$ oligomers, which, in turn, modulates long-term potentiation by controlling synaptic levels of the NMDA receptor. The excessive accumulation of $\mathrm{A} \beta$ oli-
\end{abstract}

gomers in the synaptic cleft would then be predicted to adversely affect synaptic neurotransmission. Based on these findings, we have proposed the "Metal Hypothesis of Alzheimer's Disease," which stipulates that the neuropathogenic effects of $\mathrm{A} \beta$ in Alzheimer's disease are promoted by (and possibly even dependent on) $\mathrm{A} \beta$-metal interactions. Increasingly sophisticated pharmaceutical approaches are now being implemented to attenuate abnormal $\mathrm{A} \beta$-metal interactions without causing systemic disturbance of essential metals. Small molecules targeting $\mathrm{A} \beta$-metal interactions (e.g., PBT2) are currently advancing through clinical trials and show increasing promise as disease-modifying agents for Alzheimer's disease based on the "metal hypothesis." Key Words: Copper, zinc, amyloid, free radical, oxidation, PBT2.

\section{INTRODUCTION}

Currently, the most popular hypothesis for Alzheimer's disease (AD)-related cognitive dysfunction and neuropathogenesis is the "Amyloid Cascade Hypothesis," which posits that all pathology in the AD brain occurs downstream of the excessive accumulation of $\beta$-amyloid in the CNS. ${ }^{1,2}$ However, although a central role for $\mathrm{A} \beta$ in the pathogenesis of $\mathrm{AD}$ is indisputable, based largely on genetics, considerable evidence indicates that $\mathrm{A} \beta$ production is not the sole culprit in $\mathrm{AD}$ pathogenesis. $^{2}$ This problem is central to the ability to develop disease-modifying therapies for AD. Currentlymarketed drug therapies for AD target symptom relief, but do not interdict the underlying causal pathobiology.

Address correspondence to: Ashley I. Bush, M.D., Ph.D., The Mental Health Research Institute, 155 Oak Street, Parkville, Victoria 3052, Australia. E-mail: bush@ @elix.mgh.harvard.edu, or Rudy Tanzi, Ph.D., Genetics and Aging Research Unit, Mass General Institute for Neurodegenerative Disease, Department of Neurology, Massachusetts General Hospital, Charlestown, MA 02129. E-mail: tanzi@helix.mgh. harvard.edu.
However, other more recent approaches to drug development for $\mathrm{AD}$ have been targeted at curbing disease progression. Within this realm, the greatest emphasis has been placed on blocking $\beta$-amyloid accumulation (e.g., senile plaques) in the brain. Genetic studies clearly implicate alterations in $\mathrm{A} \beta$ production in the pathogenesis of $\mathrm{AD}^{2}$; however, it remains unclear as to how $\mathrm{A} \beta$ accumulates in the brain and leads to cognitive dysfunction and dementia. Moreover, although $\mathrm{A} \beta$ is neurotoxic at nonphysiological (micromolar) concentrations in vitro, it is normally produced in the brain, ${ }^{3}$ and at physiological (nanomolar) concentrations it has even been shown to possess neurotrophic properties in cell culture. ${ }^{4-6}$ Thus, in targeting $\mathrm{A} \beta$ for the treatment of $\mathrm{AD}$, other factors influencing $\mathrm{A} \beta$ toxicity must also be elucidated and pharmaceutically addressed.

The length of $\mathrm{A} \beta$ is an important factor in $\mathrm{AD}$ pathogenesis; the less prevalent form of the peptide, $\mathrm{A} \beta 42,{ }^{7}$ is particularly enriched in $\beta$-amyloid deposits. ${ }^{89}$ Furthermore, most of the $\sim 200$ known early-onset familial AD-linked mutations in the amyloid precursor protein (APP) and pre- 
senilin genes do not increase overall production of $\mathrm{A} \beta$, but, instead they increase the ratio of $\mathrm{A} \beta 42: \mathrm{A} \beta 40{ }^{2,10}$ Synthetic $\mathrm{A} \beta 42$ aggregates more readily than $\mathrm{A} \beta 40$ and $\mathrm{A} \beta 42$ readily seeds the aggregation of $\mathrm{A} \beta 40$, in vitro. ${ }^{11,12}$ Aggregated $\mathrm{A} \beta$ (e.g., in the form of soluble oligomers) has been implicated as the neurotoxic form of the peptide., ${ }^{2,13-15}$ These pathophysical properties of $\mathrm{A} \beta$ form the basis of the amyloid cascade hypothesis, which maintains that excessive production of $\mathrm{A} \beta$ is sufficient to cause $\mathrm{AD}$. The problem with applying this hypothesis to most forms of $\mathrm{AD}$ is that the self-aggregating properties of $A \beta$ alone are insufficient to explain the accumulation of the peptide in specific brain regions of $\mathrm{AD}$ patients. Healthy people normally have soluble $\mathrm{A} \beta$ in their brains, and $\mathrm{A} \beta$ is a soluble component of all biological fluids. Therefore, it is conceivable that there may be an abnormally modified "rogue" form of soluble $\mathrm{A} \beta$ that is particularly neurotoxic in $\mathrm{AD}$. In this review, we will propose that it is the interaction of $A \beta$ with specific metals (particularly copper and zinc) that drives $\mathrm{A} \beta$ pathogenicity and downstreams $\mathrm{AD}$ pathology; this has been coined as "The Metal Hypothesis of Alzheimer's Disease."

Based on the overwhelming genetic and pathophysiological evidence supporting $A \beta$ as the culprit molecule in $\mathrm{AD}$, the major approaches for developing therapeutics to slow, stop, or reverse $\mathrm{AD}$ progression have attempted to either target $\mathrm{A} \beta$ production (e.g., secretase inhibitors and modulators), or clear $\mathrm{A} \beta$ from the brain (e.g., immunotherapy). However, other neurochemical events apart from $\mathrm{A} \beta$ production may also contribute to $\beta$-amyloid deposition and toxicity in $\mathrm{AD}$. If elevated cortical $\mathrm{A} \beta$ concentrations to be solely responsible for the deposition of $\beta$-amyloid, it would be difficult to explain why $\beta$-amyloid deposits are focal (related to synapses and the cerebrovascular lamina media) and not uniform in their distribution, especially because APP and $\mathrm{A} \beta$ are ubiquitously expressed. Moreover, to attribute $\beta$-amyloid accumulation to the presence of $\mathrm{A} \beta 42$, alone, is problematic because the peptide is a normal component of healthy CSF. ${ }^{7}$ Finally, whereas $\beta$-amyloid deposition is an age-dependent phenomenon, $\mathrm{A} \beta$ production does not appear to increase with age. Thus, other age-related stochastic changes (e.g., metal-mediated oxidative damage to neuronal cells) that generally precede $\mathrm{A} \beta$ deposition, ${ }^{16-18}$ most likely play essential roles in the biochemical events and reactions that cause $\mathrm{A} \beta$ to accumulate in specific brain regions affected in $\mathrm{AD}$.

\section{METALLOCHEMISTRY MEDIATES THE AGGREGATION AND NEUROTOXICITY OF A $\boldsymbol{\beta}$}

We first discovered in 1994 that $\mathrm{A} \beta$ becomes amyloidogenic in reaction to stoichiometric amounts of $\mathrm{Zn}^{2+}$ and $\mathrm{Cu}^{2+} \cdot{ }^{19,20}$ In the subsequent years it has become clear that $\mathrm{A} \beta$ is a metalloprotein, ${ }^{21,22}$ and that the brain's intrinsic supply of $\mathrm{Cu}^{2+}$ and $\mathrm{Zn}^{2+}$ (and possibly $\mathrm{Fe}^{3+}$ ) mediates the peptide's toxicity through radical and hydrogen peroxide production and aggregation. We first observed that $\mathrm{A} \beta$ is rapidly precipitated by $\mathrm{Zn}^{2+} .19,20,23$ Both $\mathrm{Cu}^{2+}$ and $\mathrm{Fe}^{3+}$ also induce marked $\mathrm{A} \beta$ aggregation, but only under mildly acidic conditions (e.g., $\mathrm{pH}$ 6.8-7.0), ${ }^{19,20,23}$ such as those in the brains of $\mathrm{AD}$ patients. $\mathrm{Cu}^{2+}$ precipitates $\mathrm{A} \beta$ more robustly than $\mathrm{Fe}^{3+}$, and even trace (nanomolar) concentrations of $\mathrm{Zn}^{2+}$, $\mathrm{Cu}^{2+}$, or $\mathrm{Fe}^{3+}$ in common laboratory buffers are sufficient to induce nucleation of $\mathrm{A} \beta$, which can then lead to fibrillization of the peptide solution. ${ }^{24-26}$ Interestingly, rat and mouse $\mathrm{A} \beta$ possesses amino acid substitutions that decrease metal interactions, ${ }^{20}$ perhaps explaining why these animals are exceptional among mammals for not accumulating cerebral $\mathrm{A} \beta$ amyloid with advanced age. ${ }^{27}$ On the basis of our findings regarding $\mathrm{A} \beta$-metal interactions, in 1997, we co-founded the company, Prana Biotechnology Ltd., which has since initiated a clinical program focusing on a new class of drug therapy targeting $A \beta$-metal biochemistry (see below).

$\mathrm{A} \beta$ possesses selective high- and low-affinity metal binding sites, which are histidine mediated. ${ }^{25,28,29}$ The original reported $\mathrm{Kd}$ of high-affinity $\mathrm{Zn}^{2+}$ binding was $\approx 100 \mathrm{nM}$, and for low-affinity binding it was $\approx 5$ $\mu \mathrm{M} .{ }^{19,20}$ Although there has been some contention about the exact $\mathrm{Kd}$ values for both $\mathrm{Zn}^{2+}$ and $\mathrm{Cu}^{2+}$, it is now understood that both the buffer conditions (e.g., the presence of $\mathrm{NaCl}^{30}$ ), the aggregation state of the peptide, ${ }^{19,31,32}$ and the means used for assaying the bound and free metal ions ${ }^{33}$ are critical for the observed values. However, a consensus has emerged that the $\mu$ molar concentrations of both $\mathrm{Zn}^{2+}$ and $\mathrm{Cu}^{2+}$ that are released from cortical synapses are sufficient to induce $\mathrm{A} \beta$ aggregation. ${ }^{23,32-34}$ Low-affinity $\mathrm{Zn}^{2+}$ binding mediates the precipitation of the peptide, as well as its resistance to tryptic (alpha secretase-like) cleavage. ${ }^{19} \mathrm{~A} \beta$ also possesses high- and low-affinity $\mathrm{Cu}^{2+}$ binding sites. ${ }^{24,25}$ Although the affinity of the low-affinity $\mathrm{Cu}^{2+}$ binding site is similar between $\mathrm{A} \beta 1-40$ and $\mathrm{A} \beta 1-42\left(5.0 \times 10^{-9}\right.$ $\mathrm{M})$, the affinity of the high-affinity site on $A \beta 1-42$ has been reported as $7.0 \times 10^{-18} \mathrm{M}$, which may be the product of a perturbed equilibrium caused by precipitated $\mathrm{A} \beta$ withdrawing $\mathrm{Cu}^{2+}$ from solution. This is much greater than the highest observed affinity of $A \beta 1-40$ for $\mathrm{Cu}^{2+}\left(5.0 \times 10^{-11} \mathrm{M}\right){ }^{25}$ The higher affinity of $\mathrm{A} \beta 1-42$ versus $\mathrm{A} \beta 1-40$ for $\mathrm{Cu}^{2+}$ nicely correlates with enhanced precipitation of $\mathrm{A} \beta 1-42$ by $\mathrm{Cu}^{2+}, 24,25$ increased SDSresistant dimerization of $\mathrm{A} \beta 1-42$ by $\mathrm{Cu}^{2+},{ }^{24}$ and the increased redox activity of the $\mathrm{Cu}^{2+}: \mathrm{A} \beta 1-42$ complex (see below).

$\mathrm{A} \beta$ binds equimolar amounts of $\mathrm{Cu}^{2+}$ and $\mathrm{Zn}^{2+}$ at $\mathrm{pH}$ 7.4. However, under conditions representing acidosis (pH 6.6), $\mathrm{Cu}^{2+}$ completely displaces $\mathrm{Zn}^{2+}$ from $\mathrm{A} \beta^{25}$. $\mathrm{A} \beta$ binds up to 2.5 equivalents of either $\mathrm{Cu}^{2+}$ or $\mathrm{Zn}^{2+}$, 
the fractional stoichiometry indicating that metal binding is possibly coordinated by oligomers. ${ }^{25}$ This would have implications for utilizing hexafluoroisopropranol, commonly used for monomerizing $A \beta$ in vitro. The positive cooperativity in $\mathrm{Cu}^{2+}$ binding observed for $\mathrm{A} \beta$ may be greater for $A \beta 1-42$ than for $A \beta 1-40$ because of the enhanced ability of the longer peptide to form a $\mathrm{Cu}^{2+}$. coordinating oligomer. ${ }^{35}$ Intriguingly, apolipoprotein $\mathrm{E}$ (ApoE) isoforms prevent copper-mediated aggregation of $\mathrm{A} \beta$ in a manner that correlates with their risk for $\mathrm{AD},{ }^{36}$ and the precipitation of $\mathrm{A} \beta$ by $\mathrm{Zn}^{2+}$ and $\mathrm{Cu}^{2+}$ is reversible with chelation, ${ }^{24,30,37,38}$ in contrast with fibrillization, which is irreversible.

Beyond assembling $\mathrm{A} \beta$ into oligomers and fibrils, and in binding $\mathrm{Cu}^{2+}$ or $\mathrm{Fe}^{3+}, \mathrm{A} \beta$ reduces these metal ions and produces $\mathrm{H}_{2} \mathrm{O}_{2}$ by double electron transfer to $\mathrm{O}_{2}$ (there is no evidence of $\mathrm{O}_{2}$ formation as an intermediate), ${ }^{21}$ a reaction that has since been repeatedly confirmed. ${ }^{39-41}$ This electrochemistry, which is critical for $A \beta$-induced oxidative stress and toxicity in cell culture, is partly mediated by methionine $35^{42,43}$ and tyrosine $10 .{ }^{44} \mathrm{H}_{2} \mathrm{O}_{2}$ is also formed catalytically by the cycling of copper or iron bound to $\mathrm{A} \beta$ using biological reducing agents as electron donors without net oxidation of the $\mathrm{A} \beta$ peptide. The most likely electron donors pathophysiologically are cholesterol and long-chain fatty acids, ${ }^{21,41,45-48}$ consistent with the toxicity of $A \beta$ being mediated by adherence to the cell membrane, ${ }^{42}$ and the consequent production of toxic lipid oxidation products (oxysterols and 4-hydroxynonenal [HNE]), which are elevated in affected brain tissue in $\mathrm{AD}$ and in APP transgenic mice. $^{21,41,45,46,48} \mathrm{~A} \beta$ promotes copper-mediated generation of HNE from polyunsaturated lipids, and in turn, HNE covalently modifies the histidine side chains of $\mathrm{A} \beta .^{49} \mathrm{HNE}-$ modified $\mathrm{A} \beta$ has an increased affinity for lipid membranes and an increased tendency to aggregate into amyloid fibrils. ${ }^{49}$ Thus, the pro-oxidant activity of $\mathrm{A} \beta$ ultimately leads to its own covalent modification and accelerated amyloidogenesis. It should be noted that catecholamines can also be oxidized by $\mathrm{A} \beta: \mathrm{Cu}$ complexes. ${ }^{21,50,51}$

These reactions are important because there is overwhelming evidence in the literature for oxidative injury in $\mathrm{AD}$, mediated by $\mathrm{H}_{2} \mathrm{O}_{2} \cdot \mathrm{H}_{2} \mathrm{O}_{2}$ is a pro-oxidant molecule that is the substrate for the Fenton reaction that generates the highly reactive hydroxyl radical $(\mathrm{OH} \bullet)$. $\mathrm{H}_{2} \mathrm{O}_{2}$ is freely permeable across all tissue boundaries and will react with reduced metal ions $\left(\mathrm{Fe}^{2+}, \mathrm{Cu}^{+}\right)$to generate $\mathrm{OH} \bullet$, which in turn, generates lipid peroxidation adducts, protein carbonyl modifications, and nucleic acid adducts such as 8-OH guanosine, in all cellular compartments, which typify AD neuropathology. ${ }^{52-54}$ In AD, the $\mathrm{H}_{2} \mathrm{O}_{2}$ scavenging defenses (e.g., catalase and glutathione peroxidase may be overwhelmed by the catalytic generation of $\mathrm{H}_{2} \mathrm{O}_{2}$ from the $\mathrm{A} \beta$ metalloprotein mass). The redox activity (metal reduction, $\mathrm{OH} \bullet$ and $\mathrm{H}_{2} \mathrm{O}_{2}$ formation) of $\mathrm{A} \beta$ variants is greatest for $\mathrm{A} \beta 42_{\text {human }}>$
$\mathrm{A} \beta 40_{\text {human }}>\mathrm{A} \beta 40_{\text {mouse }} \approx 0 .{ }^{55}$ This order of rank is strikingly relevant to $\mathrm{AD}$ pathogenesis, because $\mathrm{A} \beta 42$ production is enhanced by fully penetrant, early-onset familial AD mutations in APP and the presenilin genes, and $\mathrm{A} \beta 42$ is considerably more prone to aggregation into neurotoxic assemblies (vs. $\mathrm{A} \beta 40$ and rodent $\mathrm{A} \beta$ ). This redox relationship also corresponds to the neurotoxicity of the respective peptide in neuronal culture, which is largely mediated by the $\mathrm{Cu}^{2+}: \mathrm{A} \beta$ interaction. ${ }^{21,55}$ Notably, the interaction of $\mathrm{A} \beta$ with the cell membrane is promoted by binding $\mathrm{Cu}^{2+}$ and $\mathrm{Zn}^{2+} .35,56$ Conversely, copper- and iron-chelators such as triethylenetetramine block these electrochemical reactions and attenuate $\mathrm{A} \beta$ toxicity in cell culture. ${ }^{45,57}$

$\mathrm{A} \beta$ coordination of copper leads to the generation of reactive oxygen species involving the reduction of the oxidation state of the coordinated $\mathrm{Cu}^{2+}$ to $\mathrm{Cu}^{1+}$. When this reduction reaction is not accompanied by the oxidation of another moiety, such as cholesterol, ${ }^{45} \mathrm{~A} \beta$ sidechains can become oxidized. This can then lead to a variety of oxidized $A \beta$ species, as well as cross-linking of $\mathrm{A} \beta$ peptides. Mass spectrometry has shown that $\mathrm{Cu}^{2+}$ ions are able to oxygenate $\mathrm{A} \beta$, with the most likely target being the sulphur atom of methionine $35\left(\mathrm{Met}_{35}\right) \cdot{ }^{43} \mathrm{In}$ addition to $\mathrm{A} \beta$ methionine sulfoxide, a number of other adducts can be generated from copper-mediated redox reactions including aldehyde adducts to the lysine residues $^{58}$ and tyrosine modified with adducts such as L-3,4dihydroxyphenylalanine, dopamine, dopamine quinine, dihydroxyindol, and isodityrosine. ${ }^{43,59}$ 2-oxo-histidine adducts of $\mathrm{A} \beta$ have also been extracted from $\mathrm{AD}$ plaques; ${ }^{60} \mathrm{~N} 3$-pyroglutamate modified forms of $\mathrm{A} \beta$ are the main ligands for the amyloid PET ligand PIB. ${ }^{61}$ Tyrosine is particularly susceptible to free radical attack due to its conjugated aromatic ring. Elevated levels of dityrosine and 3-nitrotyrosine have been reported within neuronal lesions in $\mathrm{AD}$ brain. In the presence of $\mathrm{Cu}^{2+}$ and $\mathrm{H}_{2} \mathrm{O}_{2}, \mathrm{~A} \beta 42$ forms dityrosine cross-linked oligomers in vitro, a modification that is resistant to proteolysis. ${ }^{62}$ The formation of dityrosine cross-linked $\mathrm{A} \beta$ further facilitates aggregation, leading to higher order oligomers. ${ }^{44}$ $\mathrm{A} \beta$-generated radicals formed after reduction of copper can also form covalent adducts onto other proteins. Along these lines, peroxidases such as cycloxygenase 2 are particularly vulnerable because of the formation of dityrosine bridges, and we have previously reported that levels of cycloxygenase $2-\mathrm{A} \beta$ covalent complexes are elevated in AD brain. ${ }^{63}$

Although a wide and diverse array of hypotheses have been proposed for the mechanism by which $A \beta$ induces its neurotoxic effects, ${ }^{2}$ there is general agreement that aggregation of $\mathrm{A} \beta$ is required. Neurotoxicity has been reported for virtually every aggregate of $\mathrm{A} \beta$ tested, from dimers to mature fibrils. Along these lines, for the past several years, there has been increasing interest in soluble $\mathrm{A} \beta$ oligomers, 
which appear to be particularly toxic. ${ }^{64}$ With regard to $\mathrm{A} \beta$-metal interactions, covalent cross-linking of $\mathrm{A} \beta$ (e.g., dityrosine formation generated by copper oxidation) could conceivably contribute greatly to the formation of toxic soluble $\mathrm{A} \beta$ species. ${ }^{44}$ Interactions of $\mathrm{A} \beta$ with metal ions may also explain the increased involvement of soluble oligomeric species of $\mathrm{A} \beta$ in $\mathrm{AD}$ pathogenesis. $\mathrm{Zn}^{2+}$ and $\mathrm{Cu}^{2+}$ readily precipitate $\mathrm{A} \beta$ oligomers. ${ }^{19,31}$ One recent report has shown that the $\mathrm{N}$-terminal region of $\mathrm{A} \beta$ can access a range of metal-coordination structures, and that $\mathrm{A} \beta-\mathrm{Cu}^{2+}$ coordination correlates with peptide self-assembly and neurotoxicity. ${ }^{65}$

\section{Zinc and copper are the critical for $A \beta$ aggregation in $\mathrm{AD}$ brain}

Zinc, copper, and iron have been shown in multiple studies to be markedly enriched in $\mathrm{A} \beta$ deposits (plaques and congophilic angiopathy) in $\mathrm{AD}$ patients and in $\mathrm{AD}$ transgenic mice. ${ }^{22,66-72}$ Copper $(390 \mu \mathrm{M})$, zinc (1055 $\mu \mathrm{M})$, and iron $(940 \mu \mathrm{M})$ have been reported to be elevated by several-fold in $\mathrm{AD}$ brain as compared with normal age-matched samples (copper [70 $\mu \mathrm{M}$ ], zinc [350 $\mu \mathrm{M}]$ and iron $[340 \mu \mathrm{M}]) .{ }^{66} \mathrm{~A} \beta$ directly coordinates copper and zinc, but not iron or other metal ions, within the cores of plaques. ${ }^{21,22}$ Iron is found in the plaque periphery, but primarily complexed with ferritin in the neuritic component of plaques. ${ }^{73}$ Iron is also found together with copper and zinc within neurons and neurofibrillary tangles. ${ }^{74-76}$ Consistent with a role for $\mathrm{A} \beta$-metal interaction in $\mathrm{AD}$ pathogenesis, experiments in ZnT3 knockout mice have established that presynaptic zinc release leads to $\beta$-amyloid formation in mutant APP transgenic mice. Moreover, genetic ablation of ZnT3 markedly inhibited $\beta$-amyloid pathology and congophilic angiopathy ${ }^{69,77}$ in these mice, increasing the concentration of soluble $A \beta .{ }^{77}$ These findings suggests that soluble $\mathrm{A} \beta$ and soluble zinc exist in a dissociable equilibrium with insoluble plaque $\mathrm{A} \beta$ (containing incarcerated zinc), a process we have previously termed the "galvanization" of amyloid. ${ }^{78} \mathrm{In}$ creased amyloid deposition in female mutant APP transgenic mice also may be explained by estrogen-dependent increases in ZnT3 expression. ${ }^{79}$

Over the past decade, we have followed up on our initial findings on the contribution of $\mathrm{A} \beta$-metal interactions to $\mathrm{AD}$ pathogenesis by developing novel therapeutic approaches aimed at interfering with $\mathrm{A} \beta$-metal binding. Initially, for purposes of proof of concept, we showed that $\mathrm{Zn} / \mathrm{Cu}$-selective chelators could prevent $\mathrm{A} \beta$ aggregation in vitro, and markedly enhance the resolubilization of $\mathrm{A} \beta$ deposits from postmortem $\mathrm{AD}$ brain samples. ${ }^{80}$ The observed increase in extractable $A \beta$ from postmortem human brain specimens correlated with significant depletion in zinc (30\%) and to a lesser extent, copper. ${ }^{80}$ The ability of chelators to extract $\mathrm{A} \beta$ depended on the presence of $\mathrm{Mg}^{2+}$ and $\mathrm{Ca}^{2+}$, hence the chelating compound needed to be far more selective for $\mathrm{Zn}^{2+}$ and $\mathrm{Cu}^{2+}$, than $\mathrm{Ca}^{2+}$ and $\mathrm{Mg}^{2+} .{ }^{80}$ These results fostered the first generation of attempts to target $\mathrm{A} \beta$-metal interactions with the goal of inhibiting amyloid pathology in APP transgenic mice, which are discussed later in this review.

\section{The neurochemistry of transition metal ions in the cortex and glutamatergic synapse}

A common misconception in discussions of the pathological mechanism underlying neurological syndromes where abnormal metal homeostasis has been implicated is that neurodegeneration is brought on by toxicological exposure to $\mathrm{Cu}, \mathrm{Fe}, \mathrm{Zn}$, and $\mathrm{Mn}$. In other words, ingestion or enhanced exposure to the metals purportedly causes abnormal protein interactions, which then causes the disease. This is an important misconception to clarify. In terms of total metal concentrations, the brain has more than enough of these metal ions resident in its tissue to damage or corrupt the activities of numerous proteins and biochemical pathways. For example, the concentration of $\mathrm{Zn}^{2+}$ that is released during neurotransmission is $\approx 300 \mu \mathrm{M}$, which is more than sufficient to be rapidly neurotoxic in neuronal cell culture. ${ }^{81}$ Therefore, the brain must possess efficient homeostatic mechanisms and buffers in place to prevent the abnormal decompartmentalization of metal ions. It should also be noted that the blood-brain barrier (BBB) is relatively impermeable to fluctuating levels of plasma metal ions.

Generally, in health, biometals, iron, copper, and zinc are bound to ligands (e.g., transferrin) and not found as free species. However, recent data have documented the release of free ionic or exchangeable zinc and copper in the synaptic cleft (see as follows) on glutamatergic excitation. Consequently, zinc is also being increasingly understood to mimic calcium as a new class of second messenger. ${ }^{82}$ Furthermore, the intracellular pool of free iron, the labile iron pool, has been shown to modulate the expression of various proteins, including the APP. ${ }^{83} \mathrm{In}$ tracellular copper is considered to largely ligand-bound. However, it has also been shown to be exchangeable and transferred from protein to protein (e.g., by the copper chaperone of superoxide dismutase $1, \mathrm{CCS} 1){ }^{84}$

In the last few years, there have been several important basic discoveries about copper and zinc release, and flux at the glutamatergic synapse in the cortex and hippocampus. The glutamatergic synapse mediates long-term potentiation. It is here that $\beta$-amyloid deposits first form in $\mathrm{AD}$, and where they are most likely to damage cognitive functions. ${ }^{85}$ There has been interest in the presence of zinc and copper released by hippocampal tissue for at least 2 decades. ${ }^{82}$ Considerable evidence has supported the release of zinc as either a free or an exchangeable ionic species into the extracellular space. ${ }^{86}$ This pool of vesicular zinc is modulated by the activity of ZnT3, which is found in the membrane of glutamatergic vesicles, but not elsewhere. This pool zinc, 


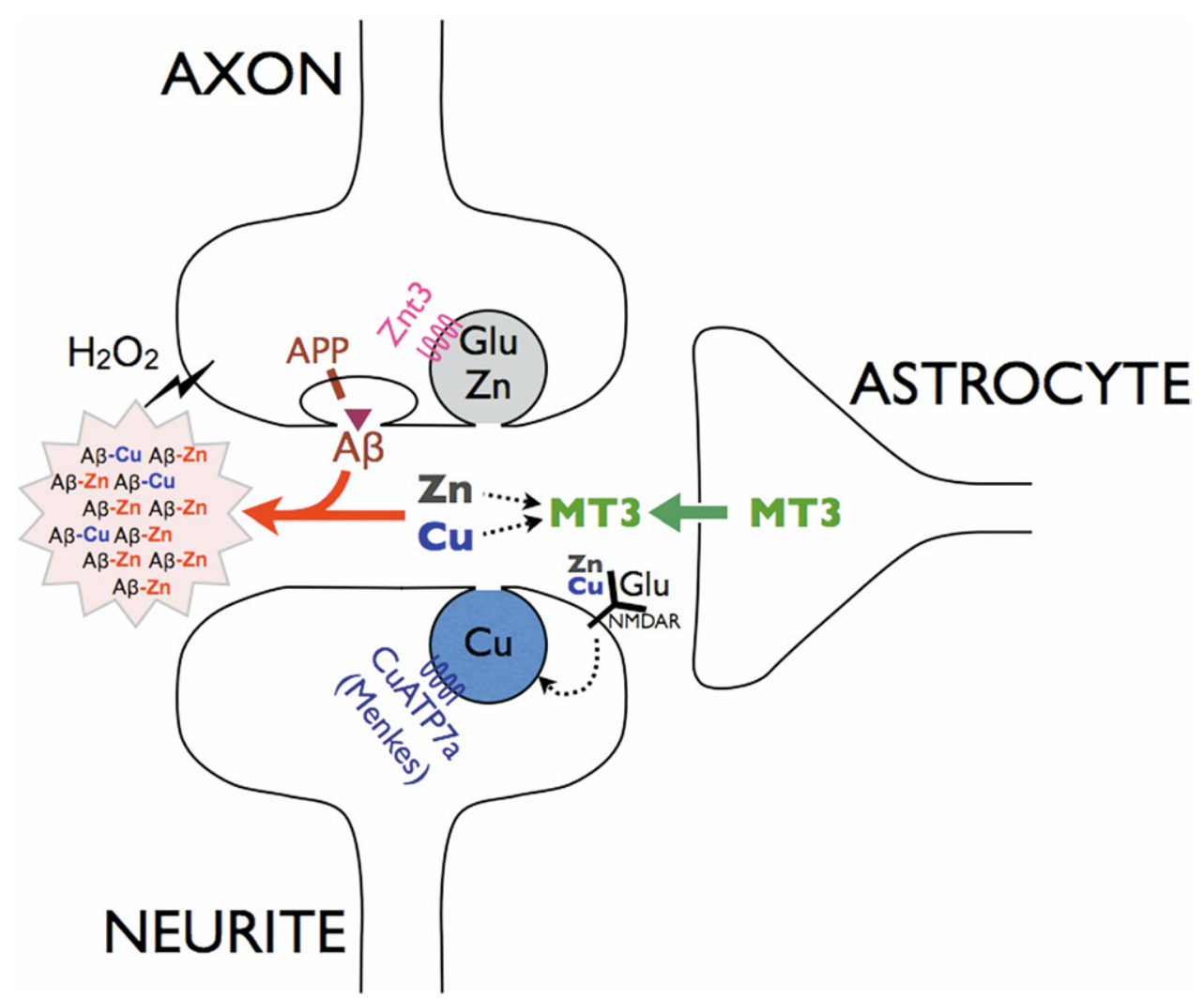

FIG. 1. Zinc, copper, and $A \beta$ in the glutamatergic synapse. $\mathrm{Zn}^{2+}$ is concentrated in the presynaptic bouton by the action of $\mathrm{ZnT3}$, where it may be co-compartmentalized with glutamate, and achieving concentrations up to $300 \mu \mathrm{M}$ in synaptic clefts. $\mathrm{Cu}^{2+}$ is released post-synaptically after NMDA-induced activation, which causes the translocation of the Menkes Cu7aATPase and its associated $\mathrm{Cu}$-laden vesicles to the synaptic cleft. $\mathrm{Cu}^{2+}$ concentrations reach $15 \mu \mathrm{M}$ in the synaptic cleft. Both $\mathrm{Cu}$ and $\mathrm{Zn}$ can quench the response of the NMDA receptor. $A \beta$ is released into the synaptic cleft where it has the potential to react with $\mathrm{Cu}$ and $\mathrm{Zn}$ to form oxidized, cross-linked soluble aggregates and precipitated amyloid. Metallothionein-3 (MT3) released into the cleft by neighboring astrocytes has the potential to ameliorate this adverse interaction, but it is decreased in Alzheimer's disease.

released together with $\mathrm{A} \beta$ during neurotransmission, also appears to suppress long-term potentiation by attenuating synaptic levels of the NMDA receptor. ${ }^{87}$ Post-synaptic NMDA neurites have also been reported to release free ionic $\mathrm{Cu}$ with NMDA activation. ${ }^{88}$ Activation of synaptic NMDA receptors in hippocampal neurons results in trafficking of Menkes ATPase and an associated efflux of copper. ${ }^{88}$ Catalytic amounts of copper can function as electron acceptors promoting the reaction of nitric oxide with thiols. Thus, it is conceivable that the release of $\mathrm{Cu}$ could function as a molecular switch to control extracellular Snitrosylaton of the NMDA receptor, a post-translational mechanism shown to be critical for modulating receptor function. ${ }^{88}$ Copper has also been reported to be specifically protective against NMDA-mediated excitotoxic cell death in primary hippocampal neurons. This protective effect of copper depends on endogenous nitric oxide production in hippocampal neurons. ${ }^{89}$ Further support for a role of copper in neurotransmission, Menkes ATPase expression is developmentally regulated, peaking during synaptogenesis, and playing a role in the endothelial cells of the BBB..$^{90,91}$

Collectively, the emerging literature has described the glutamatergic synapse to be the site of an extraordinary confluence of chemically exchangeable $\mathrm{Zn}$ and $\mathrm{Cu}$ (FIG. 1 ), which, to our knowledge, is unique in the body. This may be an explanation for how $\mathrm{A} \beta$, with its penchant for metal-induced precipitation and cross-linking, initially precipitates in this site in $\mathrm{AD}$. It has also become clear during recent years that $\mathrm{A} \beta$ oligomers can impair longterm potentiation (LTP) by promoting the endocytosis of NMDA and AMPA receptors. ${ }^{87}$ Thus, the coincident release of $A \beta$ and metals that can induce oligomerization in the synapse with glutamatergic excitation, which may represent a natural means for regulating LTP. However, an excess of $\mathrm{A} \beta$ oligomers could also pathologically impair neurotransmission in a "gain-of-function" of the same events. ${ }^{87}$ One final component in this vicinity that could modulate the availability of $\mathrm{Zn}$ and $\mathrm{Cu}$ ions in the synapses is the release of metallothionein-3 (MT3 or growth inhibitory factor [GIF]) by the neighboring astrocytes, ${ }^{92}$ which is decreased in $\mathrm{AD}^{93}$ (FIG. 1).

\section{Abnormal metal homeostasis in the aging brain and in $\mathrm{AD}$}

The metal ion content of the brain is stringently regulated with virtually no passive flux of metals from the 
circulation to the brain; movement of metals across the $\mathrm{BBB}$ is highly regulated. Although iron, copper, and zinc are being increasingly implicated in interactions with the major protein components of neurodegenerative disease, this is not merely due to increased (e.g., toxicological) levels of exposure to metals, but rather due to a breakdown in the homeostatic mechanisms that compartmentalize and regulate these metals.

The dominant risk factor associated with most neurodegenerative diseases is increasing age. Several studies in animals and humans have reported a rise in the levels of brain copper from youth to adulthood. ${ }^{94}$ However, from middle age onward, biologically available copper levels drop markedly, and are accompanied by a loss of copper-dependent enzyme activities (e.g., cytochrome c oxidase, superoxide dismutase 1 , ceruloplasmin). ${ }^{95}$ Agerelated increases in brain iron have been documented in all species examined. ${ }^{96,97}$ Indeed failure of ubiquitous ferroxidases ceruloplasmin, ferritin, ${ }^{98}$ and frataxin ${ }^{99}$ cause neurodegenerative diseases, underscoring the vulnerability of the brain to abnormal iron regulation. ${ }^{100} \mathrm{We}$ hypothesize that the breakdown in metal ion regulation in the glutamatergic synapse, possibly inhibition of reuptake, raises the average concentrations of zinc and copper in the cleft leading to excessive $\mathrm{A} \beta$ oligomerization and synaptotoxicity. Therefore, this has been the prime target for our pharmacotherapeutic approach (see as follows).

An interesting feature of the mechanism of increased AD pathology in sod2 heterozygote knockout mice crossed with Tg2576 APP transgenic mice is that brain copper, zinc, and iron levels are decreased by the mitochondrial lesion. ${ }^{101}$ This recapitulates a feature of the pathology of $\mathrm{AD}$, where $\mathrm{Cu}$ levels decrease with advanced pathology. ${ }^{95}$ Both dietary and genetic manipulations that increase brain $\mathrm{Cu}$ levels improved amyloid pathology in two strains of APP transgenic mice. ${ }^{102,103}$ However, there are also reports that exposure to copper in combination with a high-fat diet increases the risk for $\mathrm{AD} ;{ }^{104}$ a possibility that has drawn support in studies of rabbits exposed to copper and cholesterol. ${ }^{105,106}$ In contrast, $\mathrm{Zn}$ levels increase in advanced AD, correlating with brain $A \beta$ burden in humans, but not APP transgenic mice. ${ }^{95} \mathrm{Zn}$ nutritional deficiency is common in advanced age, and a recent report indicated that $\mathrm{Zn}$ deficiency in APP transgenic mice increased the volume of amyloid plaques. ${ }^{72}$ These data indicate the complexity of the disordered metal metabolism in AD. The consensus that has emerged is that zinc and copper are enriched in amyloid where they coordinate $\mathrm{A} \beta$; iron is enriched in the tissue and neuritic pathology; and there is evidence of functional copper deficiency. Therefore, pharmacotherapy that targets abnormal $\mathrm{A} \beta$ metallation is best geared not to merely be a chelation approach. Ideally the drug should release the metals trapped by $\mathrm{A} \beta$ and return them to normal metabolism; hence our interest in ionophores.

\section{Physiological interactions of APP and its processing with zinc and copper}

While the function of APP is unknown, recent evidence suggests it has a role to play in maintaining copper homeostasis. ${ }^{107-110}$ APP coordinates $\mathrm{Cu}^{+}$at its aminoterminus, and APP expression promotes the export of neuronal copper. ${ }^{108}$ A functional role for APP in copper homeostasis is supported by reports that cellular copper drives the expression of APP mRNA. ${ }^{109,110}$

Beta-secretase (BACE1) possesses a $\mathrm{Cu}^{+}$-binding site in its $\mathrm{C}$-terminal cytoplasmic domain through which it interacts with domain 1 of the copper chaperone of SOD1 (CCS1). ${ }^{111}$ The functional implications of this interaction are unknown, but they imply that copper levels can have an impact on $A \beta$ generation. Similarly, $\gamma$-secretase activity has been recently reported to be inhibited by low concentrations of $\mathrm{Zn}^{2+}$; however, the physiological implications are unclear. ${ }^{112}$

Abnormal brain copper distribution has been reported in $\mathrm{AD}$ with excessive accumulation of copper in amyloid plaques and a deficiency of copper in neighboring cells. In vitro, excess copper has been reported to inhibit $\mathrm{A} \beta$ production from APP-transfected CHO cells ${ }^{113}$; however, the effects of deficiency were not previously explored. A recent report assessed the effects of modulating intracellular copper levels on the processing of the amyloid precursor protein and the production of $\mathrm{A} \beta .^{114} \mathrm{Hu}$ man fibroblasts genetically disposed to copper accumulation secreted higher levels of soluble APP- $\alpha$ into their medium, whereas fibroblasts genetically manipulated to be profoundly copper deficient secreted predominantly soluble APP- $\beta$ and produced more amyloidogenic Ctermini (C99). Copper deficiency also markedly reduced the steady-state levels of APP mRNA, whereas APP protein levels remained constant, indicating that copper deficiency may accelerate APP translation. ${ }^{114}$ Copper deficiency in human neuroblastoma cells significantly increased the level of $\mathrm{A} \beta$ secretion, but did not affect the cleavage of the amyloid precursor protein. ${ }^{114}$

Several enzymes that degrade $A \beta$ in the extracellular milieu are zinc metalloproteinases, such as neprilysin, insulin-degrading enzyme, and matrix metalloproteinases $^{94}$. This may explain why there is an inverse correlation between CSF zinc and copper levels and CSF $\mathrm{A} \beta 42$ levels in normal men. ${ }^{115}$ This possibility was supported by the observation that adding low micromolar concentrations of zinc or copper to ex-vivo CSF samples accelerated the degradation of $\mathrm{A} \beta .{ }^{115}$ Collectively, these data have led us to propose that $A \beta$-metal complexes likely play a key pathophysiological role in $\mathrm{AD}$ at multiple levels, supporting the "metal theory of Alzheimer's disease." This hypothesis of AD pathogenesis has several 
Table 1. Features of Alzheimer's Disease explained by the Metal Theory

\begin{tabular}{|c|c|}
\hline Feature & Explanation \\
\hline $\begin{array}{l}\text { Cortical } \beta \text {-amyloid pathology does not occur in rats } \\
\text { and mice }\end{array}$ & $\begin{array}{l}\text { Rat and mouse } \mathrm{A} \beta \text { have substitutions that attenuate copper } \\
\text { and zinc interaction }\end{array}$ \\
\hline $\begin{array}{l}\beta \text {-amyloid accumulates primarily in glutamatergic } \\
\text { synapses of the neocortex, despite being broadly } \\
\text { expressed }\end{array}$ & $\begin{array}{l}\mathrm{A} \beta \text { is precipitated by } \mathrm{Zn}^{2+} \text { and cross-linked by } \mathrm{Cu}^{2+} . \mathrm{ZnT} 3 \text { is } \\
\text { uniquely expressed in neocortical glutamatergic synaptic } \\
\text { vesicles, where it functions to concentrate } \mathrm{Zn}^{2+} \text { for release } \\
\text { during neurotransmission. } \mathrm{Cu}^{2+} \text { is released from post- } \\
\text { synaptic vesicles via an NMDA receptor-mediated } \\
\text { mechanism }\end{array}$ \\
\hline $\begin{array}{l}\beta \text {-amyloid pathology is greater in female transgenic } \\
\text { APP mice }\end{array}$ & ZnT3 expression is greater in female mice \\
\hline $\begin{array}{l}\beta \text {-amyloid pathology is age-dependent, even when } \\
\text { caused by mutation }\end{array}$ & Brain metal homeostasis fatigues with age \\
\hline
\end{tabular}

advantages in explaining key missing components of the amyloid cascade hypothesis (Table 1). Namely, metalmediated effects on APP and A $\beta$ aggregation, particularly in synapses, can explain the lack of correlation of senile plaques with the degree of dementia. This hypothesis is also consistent with the synaptic $\mathrm{A} \beta$ hypothesis, ${ }^{87}$ in which metal-driven formation of $A \beta$ oligomers in synapses can impair long-term potentiation and neurotransmission. Accordingly, during the past decade, we have worked together with Prana Biotechnology to develop drugs that can block metal-mediated $\mathrm{A} \beta$ reactions as a pharmacological intervention for the treatment and prevention of $\mathrm{AD}$.

\section{Therapeutic inventions based on the metal theory of AD}

Another common misconception in envisaging therapeutic approaches to $\mathrm{AD}$, based on the metal hypothesis, is the erroneous belief that chelation (meaning the removal of metal ions from tissue) is the obvious intervention. Although there are several medical chelators, their approved use is confined to genuine situations of metal overexposure (e.g., Wilson's disease or lead toxicity) or rheumatoid arthritis. The risk of chelation therapy is that the removal of essential metal ions will lead to serious adverse effects (e.g., iron-deficiency anemia). Although these effects can (to some extent) be potentially mitigated by engineering small molecules to target specific compartments or organelles, sequestration of metals in plaques and their relative deficiency within neighboring cells dictates the need for the development of small molecules with more sophisticated properties (e.g., metal-protein attenuation compounds [MPACs] that serve as metal exchangers and ionophores).

A logical property of such small molecule MPACs is to target $\mathrm{A} \beta$ oligomerization and $\mathrm{A} \beta$-related generation of free radicals (i.e., to employ MPACs that can prevent reactive metals from participating in potentially harmful redox chemistry). Another important property of a potential MPAC is its ability to cross the BBB. This ex- cludes a large number of common metal chelators as possibilities due to their hydrophilic nature. Nevertheless, there have been two reports of blinded clinical trials of orthodox chelators for the treatment of AD. In 1991, Crapper-McLachlan et al. ${ }^{116}$ reported benefit for a 2-year period in AD patients treated with intramuscular desferrioxamine twice daily. Desferrioxamine treatment led to a significant reduction in the rate of decline of daily living skills, which the authors originally attributed to chelation of aluminum. However, desferrioxamine also chelates zinc, iron, and copper. A small double-blind trial of $34 \mathrm{AD}$ subjects with d-penicillamine or placebo reported a decrease in serum oxidative markers for a 6-month period, but no change in cognitive decline. ${ }^{117}$ However, the large dropout rate in the study led to inconclusive results.

Several metal-complexing agents have been tested for the treatment of $\mathrm{AD}$ in a variety of pre-clinical systems. Derivatives of a 14-membered saturated tetramine (e.g. the bicyclam analogue JKL169 [1,1'-xylyl bis-1,4,8,11 tetraaza cyclotetradecane]), have been shown to be effective in reducing copper levels in the cortex, and have been able to maintain normal copper levels in the blood, CSF, and corpus callossum of rats. ${ }^{118}$ The lipophillic chelator (DP109) has been shown to reduce levels of aggregated insoluble $\mathrm{A} \beta$ and conversely increased soluble $\mathrm{A} \beta$ forms in a mouse model. ${ }^{119}$ In our previous studies, oral treatment with the clioquinol (CQ; 5-chloro7-iodo-8-hydroxyquinoline) in $\mathrm{Tg} 2576$ mice resulted in a reduction of cortical deposition of amyloid (49\%) with an improvement or stability in the general health and weight parameters compared with untreated mice. ${ }^{37}$ This compound is able to cross the BBB and was able to increase brain copper and zinc levels in treated mice. CQ has a nanomolar affinity for $\mathrm{Cu}^{2+}$ and $\mathrm{Zn}^{2+},{ }^{120}$ which is sufficient to facilitate dissociation of these metal ions from the low-affinity metal binding sites of $A \beta$, thereby increasing levels of biologically available copper and zinc in the brain of treated animals. With peripheral 


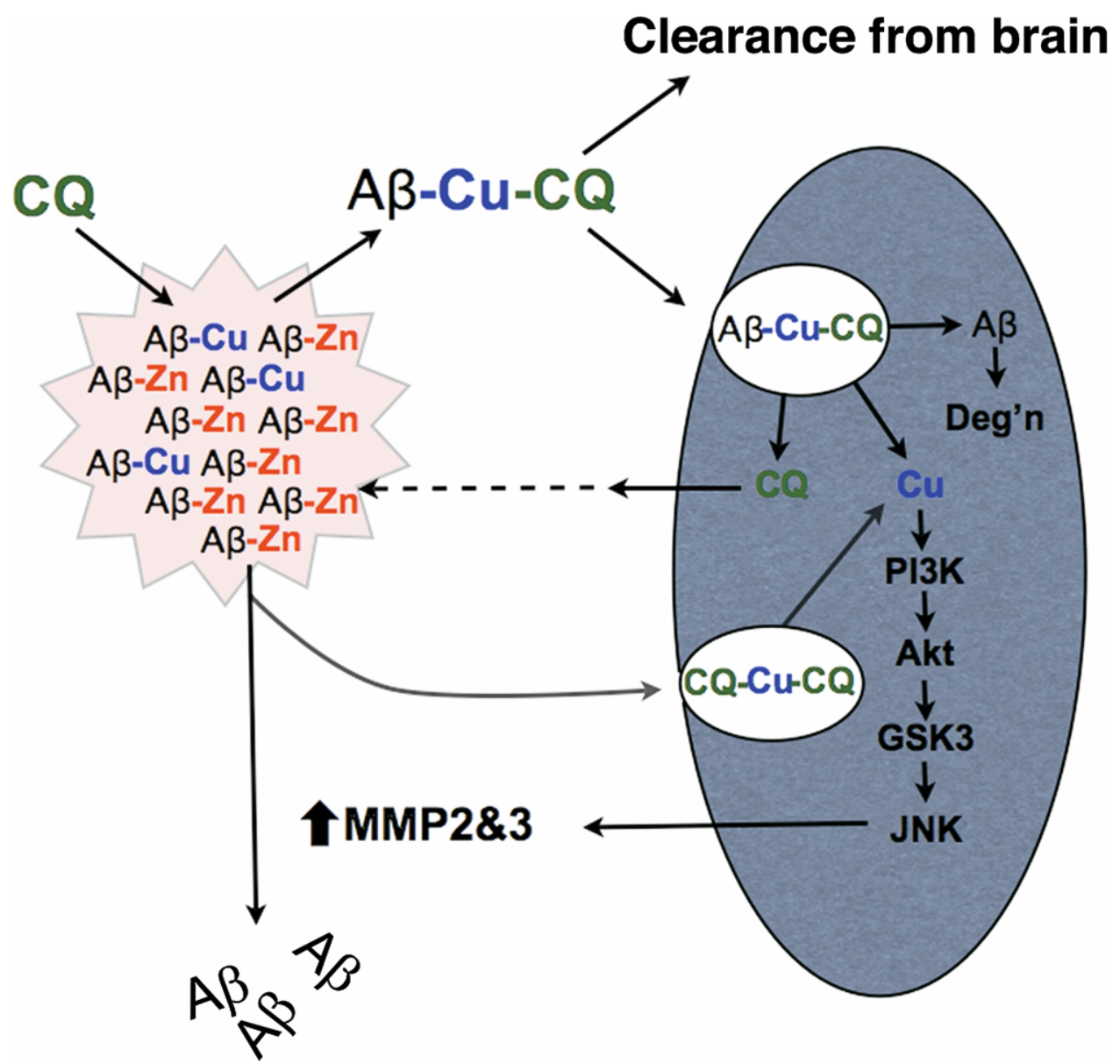

FIG. 2. Mechanism of action of clioquinol and similar metal-protein attenuation compounds (MPACs). The drug enters the brain in the metal-free form, where it is first attracted to collections of extracellular metals, a unique feature of AD. The drug combines with the metals (ionic copper or zinc) and facilitates their dissociation; the figure only shows an example for copper and CQ for simplicity, but this generalizes to $\mathrm{Zn}$ and other MPACs, such as PBT2. The dissociated metal ions may be in a ternary complex with the drug itself or in a complex with dissociated $A \beta$. These complexes are taken up by neighboring cells where the elements are separated. The metal ions (copper or zinc) can activate the phosphorylation of GSK-3 $\beta$, and the activation of matrix metalloprotease (MMP)2 and 3 . This, in turn, facilitates the breakdown and clearance of $A \beta$. Not shown are the other predicted benefits of $C Q / P B T 2$, being the dissolution of $A \beta$ aggregates, blocking of cross-linked, covalently bonded $A \beta$ oligomer formation, and the inhibition of toxic $A \beta$ redox activity. $C Q=$ clioquinol; Deg'n = degradation; GSK3 = glycogen synthase kinase 3; JNK = Jun N-terminal kinase.

dosing, CQ was demonstrated in $\mathrm{Tg} 2576$ mice to cross the BBB and bind to amyloid plaques, as well as $\mathrm{Zn}^{2+}$ metallated $\mathrm{A} \beta$ from postmortem $\mathrm{AD}$-affected brain specimens. ${ }^{120}$ In a small phase 2 clinical trial, oral administration of CQ in moderately severe AD patients for 36 weeks slowed the rate of cognitive decline and caused a reduction in plasma $A \beta 42$ levels as compared with the placebo controls. ${ }^{121}$ One mode of action of CQ is to strip copper and zinc away from $\mathrm{A} \beta$, thereby preventing oligomerization and promoting the dissolution of noncovalently cross-linked species of $A \beta$. An alternative mode of action of CQ may be as a modulator of metal levels. $\mathrm{CQ}$ appears to have strong ionophore activity and $\mathrm{CQ}: \mathrm{Cu}$ complexes mediate transport of copper into cells. ${ }^{122}$ This results in the activation of matrix metalloproteases and the subsequent degradation of $\mathrm{A} \beta .^{122}$ Therefore, compounds that target the $\mathrm{A} \beta$ :metal interaction and/or metal homeostasis would appear to have genuine therapeutic potential for treating AD. The goal with this class of MPACs is to remove the copper and zinc from $\mathrm{A} \beta$, and to relocate these metals to sites where they will be beneficial (i.e., to restore metal homeostasis). CQ has also been tested in other neurodegenerative disease models with efficacy shown in both $\mathrm{PD}^{123}$ and $\mathrm{HD}^{124}$ animal models. Both of these diseases have been associated with iron overload leading to oxidative stress and free radical generation. $\mathrm{CQ}$ was eventually terminated in $\mathrm{AD}$ clinical trials due to the generation of a di-iodo contaminant during drug manufacture. More recently, we have found that a second generation 8-hydroxy quinoline derivative of CQ, PBT-2 (Prana Biotechnology, Ltd.), has greater $\mathrm{BBB}$ penetration, significantly reduces plaque burden and $\mathrm{A} \beta$ levels in transgenic $\mathrm{AD}$ mice, improves performance of transgenic AD mice in the Morris Water Maze, and rescues $\mathrm{A} \beta$-induced impairment of LTP in hippocampal slices. Following up on these encouraging pre- 
clinical findings, Prana Biotechnology recently completed its first double-blind, placebo-controlled phase 2 clinical trial of $78 \mathrm{AD}$ patients in a 12-week trial for the treatment of mild to moderate AD. An initial report of the results (which can be viewed at: http://www. pranabio.com/company_profile/press_releases_item.asp?id $=152$ ) has revealed that the drug was safe and well-tolerated at $50 \mathrm{mg}$ and $250 \mathrm{mg}$ daily doses for 12 weeks, and that CSF A $\beta$ levels were significantly lowered at the $250 \mathrm{mg}$ dose for 12 weeks. There was also significant improvement above baseline in performance on two different executive tests (Trail-Making B and Verbal Fluency) of the Neuropsychological Test Battery after 12 weeks. These results now serve as the basis for proceeding with further phase $2 \mathrm{~b}$ or phase 3 clinical trials of what may be one of the first disease-modifying drugs based on the metal theory of AD.

With regard to mechanism, in mice, $\mathrm{CQ}$ is understood to enter the brain and to combine with metallated $A \beta$ in plaques and possibly in soluble pools. ${ }^{120} \mathrm{CQ}$ treatment of transgenic mice modestly increased brain zinc and copper levels, ${ }^{37}$ and in the phase 2 clinical trial in $\mathrm{AD}$ patients, the plasma zinc levels significantly increased (normalized from a baseline of deficiency) ${ }^{121}$; therefore, CQ (and PBT2) do not act as chelators. In cell culture, $\mathrm{CQ}-\mathrm{Cu}$ complexes enter cells where they markedly inhibit the secretion of $\mathrm{A} \beta$ by a mechanism where the peptide is degraded through upregulation of matrix metalloprotease (MMP)-2 and MMP-3. The MMP activity was increased through activation of phosphoinositol 3-kinase and Jun N-terminal kinase. CQ-Cu also promoted phosphorylation of glycogen synthase kinase-3, and this potentiated activation of Jun N-terminal kinase and degradation of $\mathrm{A} \beta 1-40 .{ }^{122}$

We propose a mechanism of action for treatment of $\mathrm{AD}$ where $\mathrm{CQ}$ or PBT2 enters the brain and is attracted to the extracellular pool of metals that are in a dissociable equilibrium with $\mathrm{A} \beta$ (e.g., in senile plaques and oligomers) (FIG. 2). CQ and PBT2 then bind zinc and copper in the $\mathrm{A} \beta$ deposits, possibly forming a ternary complex with $\mathrm{A} \beta$. We have previously seen that stripping metals away from $\mathrm{A} \beta$ leads to dissolution of $\mathrm{A} \beta$ aggregates back down to monomer. $\mathrm{A} \beta$ monomer can then be readily cleared from the brain or degraded. Along these lines, an alternative mechanism of action involves the drug-metal complex entering the cell. Then this activates MMPs and facilitates the clearance of $\mathrm{A} \beta$ (e.g., in the synapse). In both cases, CQ and PBT2 would also attenuate oxidative cross-linking of $A \beta$ oligomers into covalently bonded species, and reduce the neurotoxic redox activity of $\mathrm{A} \beta$ oligomers. Thus, in essence, the MPACs, CQ, and PBT2, most likely block A $\beta$ oligomerization and aggregation, dissolve noncross-linked $A \beta$ aggregates, induce peptidolytic degradation of $\mathrm{A} \beta$, and neutralize $\mathrm{A} \beta$ redox activity.
Another interesting approach to metal-based therapeutics for $\mathrm{AD}$ targets the increase of iron in the brains of $\mathrm{AD}$ patients. This is a more traditional iron chelation therapy, with molecules that pass the BBB and are designed to be multifunctional (by attaching a propargylamine moiety), or by exerting antioxidant or monoamine oxidase inhibitor activity. ${ }^{125-127}$ By decreasing the labile iron pool, these drugs decrease APP translation (at the 5' untranslated region iron responsive element, and hence reduce $\mathrm{A} \beta$ generation. ${ }^{128}$ Iron depletion can also inhibit hypoxia-inducible factor prolyl 4-hydroxylases, which have been shown to be neuroprotective. ${ }^{129}$ Like all metal-complexing agents, it is very difficult to achieve complete metal ion specificity with any structure, and it is likely that these molecules that are believed to target iron will also interact with copper, zinc, and other metal ions. This may have advantages in the dissolution of $\mathrm{A} \beta$ aggregates, but as previously noted, excess depletion of $\mathrm{Cu}$ and $\mathrm{Zn}$ may paradoxically exaggerate $\mathrm{AD}$ pathology. Only empirical testing can determine whether this will be of value in a clinical situation. In any event, it has become increasingly clear that emerging therapies based on the Metal Hypothesis of AD carry considerable promise as a viable therapeutic modality for treating and preventing $\mathrm{AD}$.

Acknowledgments: Dr. Tanzi is funded by the Cure Alzheimer's Fund, the Tippins Foundation, and the United States National Institutes of Health. Dr. Bush is supported by funding from the National Health \& Medical Research Council, the Australian Research Council, and the Alzheimer's Association. Both authors are shareholders and paid consultants for Prana Biotechnology, Ltd.

\section{REFERENCES}

1. Hardy JA, Higgins GA. Alzheimer disease: the amyloid cascade hypothesis. Science 1992;256:184-185.

2. Tanzi RE, Bertram L. Twenty years of the Alzheimer's disease amyloid hypothesis: a genetic perspective. Cell 2005;120:545555 .

3. Seubert P, Vigo-Pelfrey C, Esch F, et al. Isolation and quantification of soluble Alzheimer's $\beta$-peptide from biological fluids. Nature 1992;359:325-327.

4. Whitson JS, Selkoe DJ, Cotman CW. Amyloid $\beta$ protein enhances the survival of hippocampal neurons in vitro. Science 1989;243:1488-1490.

5. Whitson JS, Glabe CG, Shintani E, et al. Beta-amyloid protein promotes neuritic branching in hippocampal cultures. Neurosci Lett 1990;110:319-324.

6. Yankner BA, Duffy LK, Kirschner DA. Neurotrophic and neurotoxic effects of amyloid $\beta$ protein: reversal by tachykinin neuropeptides. Science 1990;250:279-282.

7. Vigo-Pelfrey C, Lee D, Keim P, et al. Characterization of $\beta$-amyloid peptide from human cerebrospinal fluid. J. Neurochem 1993; 61:1965-1968.

8. Masters CL, Multhaup G, Simms G, et al. Neuronal origin of a cerebral amyloid: neurofibrillary tangles of Alzheimer's disease contain the same protein as the amyloid of plaque cores and blood vessels. EMBO J 1985;4:2757-2763.

9. Kang J, Lemaire HG, Unterbeck A, et al. The precursor of Alzheimer's disease amyloid A4 protein resembles a cell-surface receptor. Nature 1987;325:733-736. 
10. Citron M, Westaway D, Xia W, et al. Mutant presenilins of Alzheimer's disease increase production of 42-residue amyloid $\beta$-protein in both transfected cells and transgenic mice. Nat Med 1997;3:67-72.

11. Hilbich C, Kisters-Woike B, Reed J, et al. Aggregation and secondary structure of synthetic amyloid $\beta$ A4 peptides of Alzheimer's disease. J Mol Biol 1991;218:149-163.

12. Jarrett JT, Berger EP, Lansbury PT, Jr.The carboxy terminus of the $\beta$ amyloid protein is critical for the seeding of amyloid formation: implications for the pathogenesis of Alzheimer's disease. Biochemistry 1993;32:4693-4697.

13. McLean C, Cherny R, Fraser F, et al. Soluble pool of A $\beta$ amyloid as a determinant of severity of neurodegeneration in Alzheimer's Disease. Annals of Neurology 1999;46:860-866.

14. Wang J, Dickson DW, Trojanowski JQ, et al. The levels of soluble versus insoluble brain Abeta distinguish Alzheimer's disease from normal and pathologic aging. Exp Neurol 1999;158: 328-337.

15. Lue LF, Kuo YM, Roher AE, et al. Soluble amyloid beta peptide concentration as a predictor of synaptic change in Alzheimer's disease. Am J Pathol 1999;155:853-862.

16. Nunomura A, Perry G, Pappolla MA, et al. RNA oxidation is a prominent feature of vulnerable neurons in Alzheimer's disease. J Neurosci 1999;19:1959-1964.

17. Nunomura A, Perry G, Pappolla MA, et al. Neuronal oxidative stress precedes amyloid-beta deposition in Down syndrome. J Neuropathol Exp Neurol 2000;59:1011-1017.

18. Nunomura A, Perry G, Aliev G, et al. Oxidative damage is the earliest event in Alzheimer disease. J Neuropathol Exp Neurol 2001;60:759-767.

19. Bush AI, Pettingell WH, Jr., Paradis MD, et al. Modulation of A $\beta$ adhesiveness and secretase site cleavage by zinc. J Biol Chem 1994;269:12152-12158.

20. Bush AI, Pettingell WH, Multhaup G, et al. Rapid induction of Alzheimer A $\beta$ amyloid formation by zinc. Science 1994;265: 1464-1467.

21. Opazo C, Huang X, Cherny R, et al. Metalloenzyme-like activity of Alzheimer's disease $\beta$-amyloid: $\mathrm{Cu}$-dependent catalytic conversion of dopamine, cholesterol and biological reducing agents to neurotoxic H2O2. J Biol Chem 2002;277:40302-40308.

22. Dong J, Atwood CS, Anderson VE, et al. Metal binding and oxidation of amyloid-beta within isolated senile plaque cores: Raman microscopic evidence. Biochemistry 2003;42:2768-2773.

23. Ha C, Ryu J, Park CB. Metal ions differentially influence the aggregation and deposition of Alzheimer's beta-amyloid on a solid template. Biochemistry 2007;46:6118-6125.

24. Atwood CS, Moir RD, Huang X, et al. Dramatic aggregation of Alzheimer $\mathrm{A} \beta$ by $\mathrm{Cu}(\mathrm{II})$ is induced by conditions representing physiological acidosis. J Biol Chem 1998;273:12817-12826.

25. Atwood CS, Scarpa RC, Huang X, et al. Characterization of copper interactions with Alzheimer $\mathrm{A} \beta$ peptides- identification of an attomolar affinity copper binding site on $A \beta 1-42$. J Neurochem 2000;75:1219-1233.

26. Huang X, Atwood CS, Moir RD, et al. Trace metal contamination initiates the apparent auto-aggregation, amyloidosis, and oligomerization of Alzheimer's Abeta peptides. J Biol Inorg Chem 2004;9:954-960.

27. Vaughan DW, Peters A. The structure of neuritic plaques in the cerebral cortex of aged rats. J Neuropathol Exp Neurol 1981;40: 472-487.

28. Syme CD, Viles JH. Solution (1)H NMR investigation of $\mathrm{Zn}(2+)$ and $\mathrm{Cd}(2+)$ binding to amyloid-beta peptide (Abeta) of Alzheimer's disease. Biochim Biophys Acta 2006;1764:246-256.

29. Danielsson J, Pierattelli R, Banci L, et al. High-resolution NMR studies of the zinc-binding site of the Alzheimer's amyloid betapeptide. Febs J 2007;274:46-59.

30. Huang X, Atwood CS, Moir RD, et al. Zinc-induced Alzheimer's A $\beta 1-40$ aggregation is mediated by conformational factors. J Biol Chem 1997;272:26464-26470.

31. Garai K, Sengupta P, Sahoo B, et al. Selective destabilization of soluble amyloid beta oligomers by divalent metal ions. Biochem Biophys Res Commun 2006;345:210-215.
32. Jun $S$, Saxena $S$. The aggregated state of amyloid-beta peptide in vitro depends on $\mathrm{Cu} 2+$ ion concentration. Angewandte Chemie (International ed) 2007;46:3959-3961.

33. Tougu V, Karafin A, Palumaa P. Binding of zinc(II) and copper(II) to the full-length Alzheimer's amyloid-beta peptide. J Neurochem 2008;104:1249-1259.

34. Stellato F, Menestrina G, Dalla Serra M, et al. Metal binding in amyloid beta-peptides shows intra- and inter-peptide coordination modes. Eur Biophys J 2006;35:340-351.

35. Curtain C, Ali F, Volitakis I, et al. Alzheimer's disease amyloidbinds $\mathrm{Cu}$ and $\mathrm{Zn}$ to generate an allosterically-ordered membranepenetrating structure containing SOD-like subunits. J Biol Chem 2001;276:20466-20473.

36. Moir RD, Atwood CS, Romano DM, et al. Differential effects of apolipoprotein $\mathrm{E}$ isoforms on metal-induced aggregation of A $\beta$ using physiological concentrations. Biochemistry 1999; 38:4595-4603.

37. Cherny RA, Atwood CS, Xilinas ME, et al. Treatment with a copper-zinc chelator markedly and rapidly inhibits $\beta$-amyloid accumulation in Alzheimer's disease transgenic mice. Neuron 2001;30:665-676.

38. Hu WP, Chang GL, Chen SJ, et al. Kinetic analysis of betaamyloid peptide aggregation induced by metal ions based on surface plasmon resonance biosensing. J Neurosci Methods 2006; 154:190-197.

39. Tabner BJ, Turnbull S, El-Agnaf OM, et al. Formation of hydrogen peroxide and hydroxyl radicals from $\mathrm{A}($ beta) and alphasynuclein as a possible mechanism of cell death in Alzheimer's disease and Parkinson's disease. Free Radic Biol Med 2002;32: 1076-1083.

40. Dikalov SI, Vitek MP, Mason RP. Cupric-amyloid beta peptide complex stimulates oxidation of ascorbate and generation of hydroxyl radical. Free Radic Biol Med 2004;36:340-347.

41. Nelson TJ, Alkon DL. Oxidation of cholesterol by amyloid precursor protein and beta-amyloid peptide. J Biol Chem 2005;280: 7377-7387.

42. Ciccotosto GD, Tew D, Curtain CC, et al. Enhanced toxicity and cellular binding of a modified amyloid beta peptide with a methionine to valine substitution. J Biol Chem 2004;279:4252842534.

43. Ali FE, Separovic F, Barrow CJ, et al. Methionine regulates copper/hydrogen peroxide oxidation products of Abeta. J Pept Sci 2005;11:353-360.

44. Barnham KJ, Haeffner F, Ciccotosto GD, et al. Tyrosine gated electron transfer is key to the toxic mechanism of Alzheimer's disease beta-amyloid. Faseb J 2004;18:1427-1429.

45. Puglielli L, Friedlich AL, Setchell KDR, et al. Cholesterol oxidase mimetic activity of Alzheimer's Disease $\beta$-amyloid. J Clin Investig 2005;115:2556-2563.

46. Haeffner F, Smith DG, Barnham KJ, et al. Model studies of cholesterol and ascorbate oxidation by copper complexes: relevance to Alzheimer's disease beta-amyloid metallochemistry. J Inorg Biochem 2005;99:2403-2422.

47. Murray IV, Sindoni ME, Axelsen PH. Promotion of oxidative lipid membrane damage by amyloid beta proteins. Biochemistry 2005;44:12606-12613.

48. Smith DP, Smith DG, Curtain CC, et al. Copper-mediated amyloid-beta toxicity is associated with an intermolecular histidine bridge. J Biol Chem 2006;281:15145-15154.

49. Murray IV, Liu L, Komatsu H, et al. Membrane-mediated amyloidogenesis and the promotion of oxidative lipid damage by amyloid beta proteins. J Biol Chem 2007;282:9335-9345.

50. da Silva GF, Ming LJ. Alzheimer's disease related copper(II)beta-amyloid peptide exhibits phenol monooxygenase and catechol oxidase activities. Angewandte Chemie (International ed) 2005;44:5501-5504.

51. da Silva GF, Ming LJ. Metallo-ROS in Alzheimer's disease: oxidation of neurotransmitters by CuII-beta-amyloid and neuropathology of the disease. Angewandte Chemie (International ed) 2007;46:3337-3341.

52. Smith MA, Perry G, Richey PL, et al. Oxidative damage in Alzheimer's. Nature 1996;382:120-121.

53. Smith MA, Richey Harris PL, Sayre LM, et al. Widespread 
peroxynitrite-mediated damage in Alzheimer's disease. J Neurosci 1997;17:2653-2657.

54. Markesbery WR, Lovell MA. Damage to lipids, proteins, DNA, and RNA in mild cognitive impairment. Arch Neurol 2007;64: 954-956.

55. Huang X, Cuajungco MP, Atwood CS, et al. Cu(II) potentiation of Alzheimer $\mathrm{A} \beta$ neurotoxicity: correlation with cell-free hydrogen peroxide production and metal reduction. J Biolog Chem 1999;274:37111-37116.

56. Curtain CC, Ali FE, Smith DG, et al. Metal ions, $\mathrm{pH}$ and cholesterol regulate the interactions of Alzheimer's disease amyloid- $\beta$ peptide with membrane lipid. J Biol Chem 2003;278.

57. Abramov AY, Canevari L, Duchen MR. Changes in intracellular calcium and glutathione in astrocytes as the primary mechanism of amyloid neurotoxicity. J Neurosci 2003;23:5088-5095.

58. Chen K, Kazachkov M, Yu PH. Effect of aldehydes derived from oxidative deamination and oxidative stress on beta-amyloid aggregation; pathological implications to Alzheimer's disease. J Neural Transm 2007;114:835-839.

59. Ali FE, Leung A, Cherny RA, et al. Dimerisation of N-acetyl-Ltyrosine ethyl ester and Abeta peptides via formation of dityrosine. Free Radic Res 2006;40:1-9.

60. Metodiewa D. Molecular mechanisms of cellular injury produced by neurotoxic amino acids that generate reactive oxygen species. Amino Acids 1998;14:181-187.

61. Maeda J, Ji B, Irie T, et al. Longitudinal, quantitative assessment of amyloid, neuroinflammation, and anti-amyloid treatment in a living mouse model of Alzheimer's disease enabled by positron emission tomography. J Neurosci 2007;27:10957-10968.

62. Atwood CS, Perry G, Zeng H, et al. Copper mediates dityrosine cross-linking of alzheimer's amyloid-beta. Biochemistry 2004; 43:560-568.

63. Nagano S, Huang X, Moir RD, et al. Peroxidase activity of COX-2 cross-links Abeta and generates Abeta: COX-2 heterooligomers that are increased in Alzheimer's disease. J Biol Chem 2004;279:14673-14678.

64. Lesne S, Koh MT, Kotilinek L, et al. A specific amyloid-beta protein assembly in the brain impairs memory. Nature 2006;440: 352-357.

65. Dong J, Canfield JM, Mehta AK, et al. Engineering metal ion coordination to regulate amyloid fibril assembly and toxicity. Proc Natl Acad Sci U S A 2007;104:13313-13318.

66. Lovell MA, Robertson JD, Teesdale WJ, et al. Copper, iron and zinc in Alzheimer's disease senile plaques. J Neurol Sci 1998; 158:47-52.

67. Lee J-Y, Mook-Jung I, Koh J-Y. Histochemically reactive zinc in plaques of the Swedish mutant beta-amyloid precursor protein transgenic mice. J Neurosci 1999;19;RC10:1-5.

68. Suh SW, Jensen KB, Jensen MS, et al. Histochemically-reactive zinc in amyloid plaques, angiopathy, and degenerating neurons of Alzheimer's diseased brains. Brain Res 2000;852:274-278.

69. Friedlich AL, Lee JY, van Groen T, et al. Neuronal zinc exchange with the blood vessel wall promotes cerebral amyloid angiopathy in an animal model of Alzheimer's disease. J Neurosci 2004;24: 3453-3459.

70. Stoltenberg M, Bruhn M, Sondergaard C, et al. Immersion autometallographic tracing of zinc ions in Alzheimer beta-amyloid plaques. Histochem Cell Biol 2005;123:605-611.

71. Miller LM, Wang Q, Telivala TP, et al. Synchrotron-based infrared and $\mathrm{X}$-ray imaging shows focalized accumulation of $\mathrm{Cu}$ and Zn co-localized with beta-amyloid deposits in Alzheimer's disease. J Struct Biol 2006;155:30-37.

72. Stoltenberg M, Bush AI, Bach G, et al. Amyloid plaques arise from zinc-enriched cortical layers in APP/PS1 transgenic mice and are paradoxically enlarged with dietary zinc deficiency. Neuroscience 2007; 150:357-369.

73. Grundke-Iqbal I, Fleming J, Tung YC, et al. Ferritin is a component of the neuritic (senile) plaque in Alzheimer dementia. Acta. Neuropathol (Berl) 1990;81:105-110.

74. Bouras C, Giannakopoulos P, Good PF, et al. A laser microprobe mass analysis of brain aluminum and iron in dementia pugilistica: comparison with Alzheimer's disease. Eur Neurol 1997;38:5358 .
75. Morris CM, Kerwin JM, Edwardson JA. Non-haem iron histochemistry of the normal and Alzheimer's disease hippocampus. Neurodegeneration 1994;3:267-275.

76. LeVine SM. Iron deposits in multiple sclerosis and Alzheimer's disease brains. Brain Res 1997;760:298-303.

77. Lee J-Y, Cole TB, Palmiter RD, et al. Contribution by synaptic zinc to the gender-disparate plaque formation in human Swedish mutant APP transgenic mice. Proc Natl Acad Sci U S A 2002; 99:7705-7710.

78. Bush AI, Tanzi RE. The galvanization of beta-amyloid in Alzheimer's disease. Proc Natl Acad Sci U S A 2002;99:7317-7319.

79. Lee J-Y, Kim J-H, Hong SH, et al. Estrogen decreases zinc transporter 3 expression and synaptic vesicle zinc levels in mouse brain. J Biol Chem 2004;279:8602-8607.

80. Cherny RA, Legg JT, McLean CA, et al. Aqueous dissolution of Alzheimer's disease $\mathrm{A} \beta$ amyloid deposits by biometal depletion. J Biol Chem 1999;274:23223-23228.

81. Frederickson CJ. Neurobiology of zinc and zinc-containing neurons. Int Rev Neurobiol 1989;31:145-328.

82. Frederickson CJ, Koh JY, Bush AI. The neurobiology of zinc in health and disease. Nat Rev Neurosci 2005;6:449-462.

83. Rogers J, Randall J, Cahill C, et al. An iron-responsive element type II in the 5' untranslated region of the Alzheimer's amyloid precursor protein transcript. J Biol Chem 2002;277:45518-45528.

84. Son M, Puttaparthi K, Kawamata H, et al. Overexpression of CCS in G93A-SOD1 mice leads to accelerated neurological deficits with severe mitochondrial pathology. Proc Natl Acad Sci U S A 2007; 104:6072-6077.

85. Terry RD, Masliah E, Salmon DP, et al. Physical basis of $\operatorname{cog}$ nitive alterations in Alzheimer's disease: synapse loss is the major correlate of cognitive impairment. Ann Neurol 1991;30:572-580.

86. Frederickson CJ, Giblin LJ, 3rd, Balaji RV, et al. Synaptic release of zinc from brain slices: factors governing release, imaging, and accurate calculation of concentration. J Neurosci Meth 2006;154: $19-29$.

87. Tanzi RE. The synaptic Abeta hypothesis of Alzheimer disease Nat Neurosci, 2005;8:977-979.

88. Schlief ML, Craig AM, Gitlin JD. NMDA receptor activation mediates copper homeostasis in hippocampal neurons. J Neurosci 2005;25:239-246.

89. Schlief ML, West T, Craig AM, et al. Role of the Menkes coppertransporting ATPase in NMDA receptor-mediated neuronal toxicity. Proc Natl Acad Sci U S A 2006;103:14919-14924.

90. El Meskini R, Crabtree KL, Cline LB, et al. ATP7A (Menkes protein) functions in axonal targeting and synaptogenesis. Mol Cell Neurosci 2007;34:409-421.

91. Niciu MJ, Ma XM, El Meskini R, et al. Altered ATP7A expression and other compensatory responses in a murine model of Menkes disease. Neurobiol Dis 2007;27:278-291.

92. Uchida Y, Gomi F, Masumizu T, et al. Growth inhibitory factor prevents neurite extension and the death of cortical neurons caused by high oxygen exposure through hydroxyl radical scavenging. J Biol Chem 2002;277:32353-32359.

93. Uchida Y, Takio K, Titani K, et al. The growth-inhibitory factor that is deficient in the Alzheimer's disease brain is a 68-amino acid metallothionein-like protein. Neuron 1991;7:337-347.

94. Adlard PA, Bush AI. Metals and Alzheimer's disease. J Alzheimer's Dis 2006;10:145-163.

95. Religa D, Strozyk D, Cherny RA, et al. Elevated cortical zinc in Alzheimer disease. Neurology 2006;67:69-75

96. Hardy PA, Gash D, Yokel R, et al. Correlation of R2 with total iron concentration in the brains of rhesus monkeys. J Magn Reson Imaging 2005;21:118-127.

97. Suh JH, Moreau R, Heath SH, et al. Dietary supplementation with (R)-alpha-lipoic acid reverses the age-related accumulation of iron and depletion of antioxidants in the rat cerebral cortex. Redox Rep 2005;10:52-60.

98. Chinnery PF, Crompton DE, Birchall D, et al. Clinical features and natural history of neuroferritinopathy caused by the FTL1 460InsA mutation. Brain 2007;130:110-119.

99. Mantovan MC, Martinuzzi A, Squarzanti F, et al. Exploring mental status in Friedreich's ataxia: a combined neuropsycholog- 
ical, behavioral and neuroimaging study. Eur $\mathrm{J}$ Neurol 2006;13:827-835.

100. Zecca L, Youdim MB, Riederer P, et al. Iron, brain ageing and neurodegenerative disorders. Nat Rev Neurosci 2004;5:863-873.

101. Melov S, Adlard PA, Morten K, et al. Mitochondrial oxidative stress causes hyperphosphorylation of tau. PLoS ONE 2007;2: e536.

102. Bayer TA, Schafer S, Simons A, et al. Dietary Cu stabilizes brain superoxide dismutase 1 activity and reduces amyloid A $\{$ beta\} production in APP23 transgenic mice. Proc Natl Acad Sci U S A 2003;100:14187-14192.

103. Phinney AL, Drisaldi B, Schmidt SD, et al. In vivo reduction of amyloid-beta by a mutant copper transporter. Proc Natl Acad Sci U S A 2003;100:14193-14198.

104. Morris MC, Evans DA, Tangney CC, et al. Dietary copper and high saturated and trans fat intakes associated with cognitive decline. Arch Neurol 2006;63:1085-1088.

105. Sparks DL, Schreurs BG. Trace amounts of copper in water induce beta-amyloid plaques and learning deficits in a rabbit model of Alzheimer's disease. Proc Natl Acad Sci U S A 2003; 100:11065-11069.

106. Sparks DL, Friedland R, Petanceska S, et al. Trace copper levels in the drinking water, but not zinc or aluminum influence CNS Alzheimer-like pathology. J Nutr Health Aging 2006;10:247254.

107. Maynard CJ, Cappai R, Volitakis I, et al. Overexpression of Alzheimer's disease $\beta$-amyloid opposes the age-dependent elevations of brain copper and iron levels. J Biol Chem 2002;277: 44670-44676.

108. Bellingham SA, Ciccotosto GD, Needham BE, et al. Gene knockout of amyloid precursor protein and amyloid precursor-like protein-2 increases cellular copper levels in primary mouse cortical neurons and embryonic fibroblasts. J Neurochem 2004;91:423428.

109. Bellingham SA, Lahiri DK, Maloney B, et al. Copper depletion down-regulates expression of the Alzheimer's disease amyloid-beta precursor protein gene. J Biol Chem 2004;279:20378-20386.

110. Armendariz AD, Gonzalez M, Loguinov AV, et al. Gene expression profiling in chronic copper overload reveals upregulation of Prnp and App. Physiol Genomics 2004;20:45-54.

111. Angeletti B, Waldron KJ, Freeman KB, et al. BACE1 cytoplasmic domain interacts with the copper chaperone for superoxide dismutase-1 and binds copper. J Biol Chem 2005;280:1793017937.

112. Hoke DE, Tan JL, Ilaya NT, et al. In vitro gamma-secretase cleavage of the Alzheimer's amyloid precursor protein correlates to a subset of presenilin complexes and is inhibited by zinc. Febs J 2005;272:5544-5557.

113. Borchardt T, Camakaris J, Cappai R, et al. Copper inhibits betaamyloid production and stimulates the non-amyloidogenic pathway of amyloid-precursor-protein secretion. Biochem J 1999;344 Pt 2:461-467.

114. Cater M, McInnes K, Li Q-X, et al. Intracellular copper deficiency increases amyloid-beta secretion by diverse mechanisms. J Biochem 2008;412:141-152.

115. Strozyk D, Launer LJ, Adlard PA, et al. Zinc and copper modu- late Alzheimer Abeta levels in human cerebrospinal fluid. Neurobiol Aging 2008; (in press).

116. Crapper-McLachlan DR, Dalton AJ, Kruck TPA, et al. Intramuscular desferrioxamine in patients with Alzheimer's disease. Lancet 1991;337:1304-1308.

117. Squitti R, Rossini PM, Cassetta E, et al. D-penicillamine reduces serum oxidative stress in Alzheimer's disease patients. Eur J Clin Invest 2002;32:51-59.

118. Moret V, Laras Y, Pietrancosta N, et al. 1,1'-Xylyl bis-1,4,8,11tetraaza cyclotetradecane: a new potential copper chelator agent for neuroprotection in Alzheimer's disease. Its comparative effects with clioquinol on rat brain copper distribution. Bioorg Med Chem Lett 2006;16:3298-3301.

119. Lee JY, Friedman JE, Angel I, et al. The lipophilic metal chelator DP-109 reduces amyloid pathology in brains of human betaamyloid precursor protein transgenic mice. Neurobiol Aging 2004;25:1315-1321.

120. Opazo C, Luza S, Villemagne VL, et al. Radioiodinated clioquinol as a biomarker for $\beta$-amyloid:Zn2 + complexes in Alzheimer's disease. Aging Cell 2006;5:69-79.

121. Ritchie CW, Bush AI, Mackinnon A, et al. Metal-protein attenuation with iodochlorhydroxyquin (clioquinol) targeting $\mathrm{A} \beta$ amyloid deposition and toxicity in Alzheimer's disease: a pilot phase 2 clinical trial. Arch Neurol 2003;60:1685-1691.

122. White AR, Du T, Laughton KM, et al. Degradation of the Alzheimer disease amyloid beta-peptide by metal-dependent up-regulation of metalloprotease activity. J Biol Chem 2006; 281:17670-17680.

123. Kaur D, Yantiri F, Kumar J, et al. Genetic or pharmacological iron chelation prevents MPTP-Induced neurotoxicity in vivo: a novel therapy for Parkinson's Disease. Neuron 2003;37:923-933.

124. Nguyen T, Hamby A, Massa SM. Clioquinol down-regulates mutant huntingtin expression in vitro and mitigates pathology in a Huntington's disease mouse model. Proc Natl Acad Sci U S A 2005;102:11840-11845.

125. Yogev-Falach M, Bar-Am O, Amit T, et al. A multifunctional, neuroprotective drug, ladostigil (TV3326), regulates holo-APP translation and processing. Faseb J 2006;20:2177-2179.

126. Avramovich-Tirosh Y, Amit T, Bar-Am O, et al. Therapeutic targets and potential of the novel brain- permeable multifunctional iron chelator-monoamine oxidase inhibitor drug, M-30, for the treatment of Alzheimer's disease. J Neurochem 2007;100: 490-502.

127. Avramovich-Tirosh Y, Reznichenko L, Mit T, et al. Neurorescue activity, APP regulation and amyloid-beta peptide reduction by novel multi-functional brain permeable iron- chelating- antioxidants, M-30 and green tea polyphenol, EGCG. Curr Alzheimer Res 2007;4:403-411.

128. Reznichenko L, Amit T, Zheng H, et al. Reduction of ironregulated amyloid precursor protein and beta-amyloid peptide by (-)-epigallocatechin-3-gallate in cell cultures: implications for iron chelation in Alzheimer's disease. J Neurochem 2006;97: 527-536.

129. Siddiq A, Ayoub IA, Chavez JC, et al. Hypoxia-inducible factor prolyl 4-hydroxylase inhibition. A target for neuroprotection in the central nervous system. J Biol Chem 2005;280:41732-41743. 